
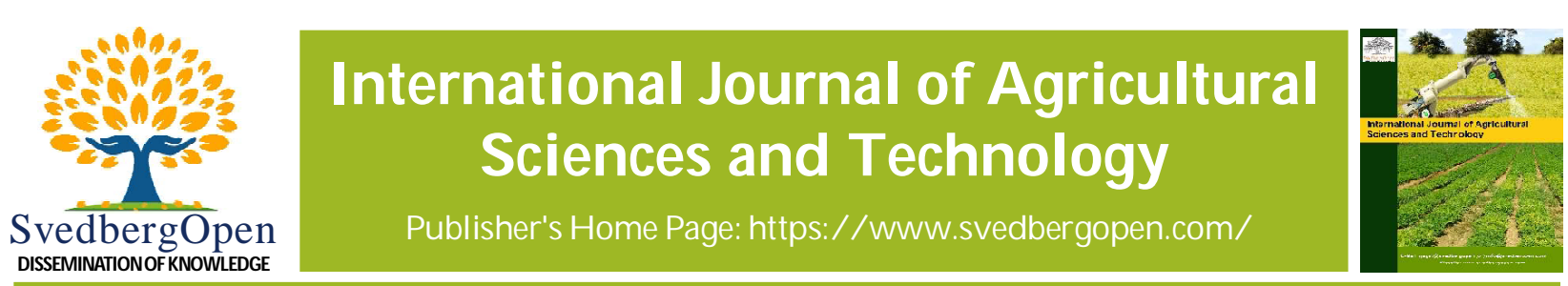

\title{
Agricultural research structure and productivity in Bulgaria
}

\author{
Hrabrin Bachev ${ }^{1 *}$
}

${ }^{1}$ Institute of Agricultural Economics, Sofia, Bulgaria. E-mail: hbachev@yahoo.com

\begin{tabular}{|c|c|}
\hline $\begin{array}{l}\text { Article Info } \\
\text { Volume 1, Issue 2, May } 2021 \\
\text { Received : } 03 \text { January } 2021 \\
\text { Accepted : } 09 \text { April } 2021 \\
\text { Published : } 05 \text { May } 2021 \\
\text { doi: 10.51483/IJAGST.1.2.2021.12-26 }\end{array}$ & 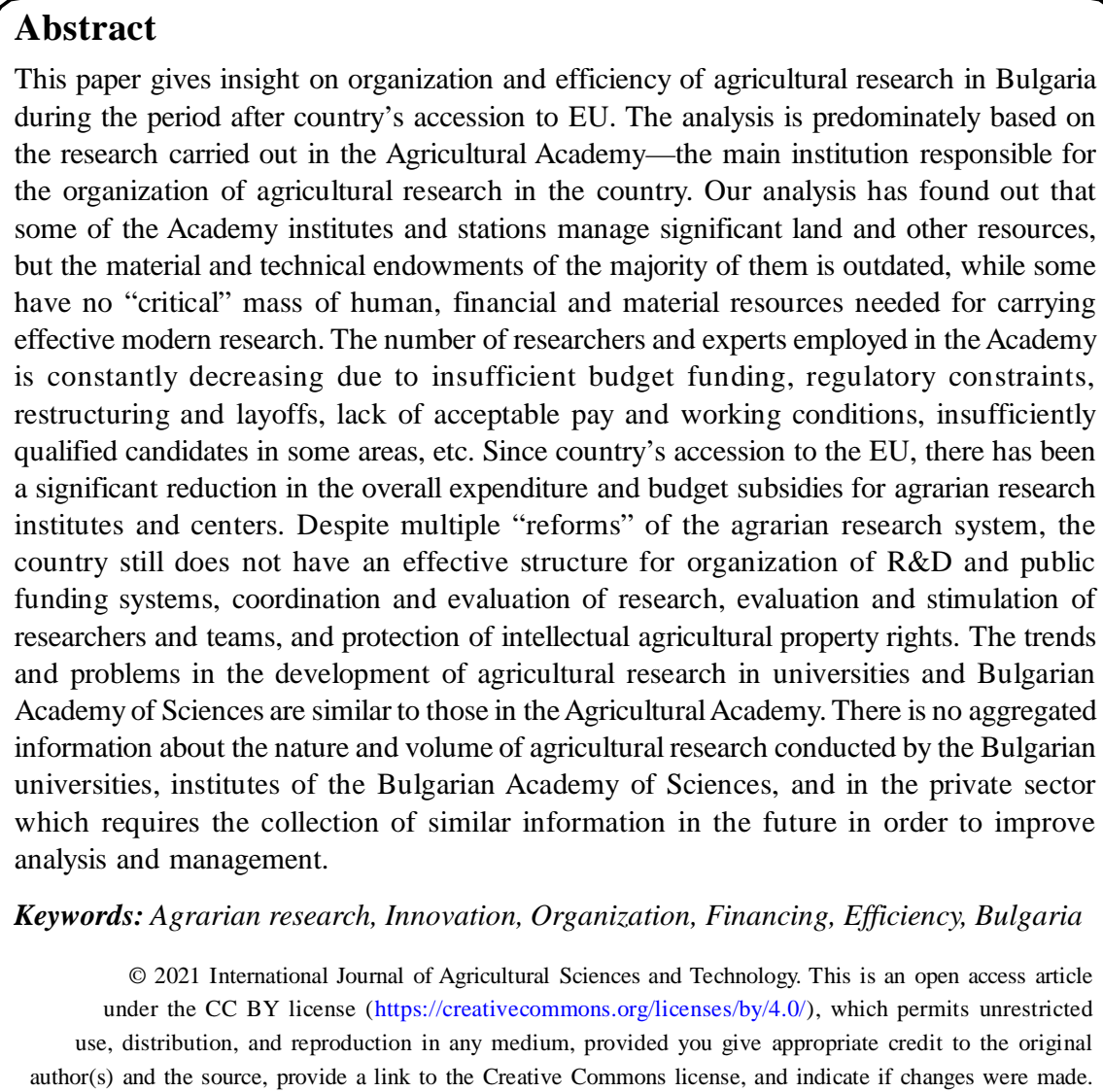 \\
\hline
\end{tabular}

\section{Introduction}

"Stimulating and sharing knowledge, innovation, digitalization and promoting their greater use" is set as one of the strategic ("horizontal") objective in the new 2021-2027 programming period for implementation of the European Union (EU) Common Agricultural Policy (CAP) (European Commission, 2018). In many other countries, regular in-depth analyzes of the state, efficiency and development factors of the Agricultural Knowledge and Innovation System (AKIS) and its major components such as Agrarian Research, Agrarian Education, Agrarian Information, etc. are made (Anandajayasekeram and Gebremedhind, 2009; Antle et al., 2017; Bachev, 2013; Chartier et al., 2015; EIP-AGRI EU SCAR, 2012; FAO, 2019; Touzard et al., 2015; Özçatalbaş, 2017; USDA, 2019; Weißhuhn et al., 2018; World Bank, 2006; Virmani, 2013).

\footnotetext{
* Corresponding author: Hrabrin Bachev, Institute of Agricultural Economics, Sofia, Bulgaria. E-mail: hbachev@yahoo.com
} 
In Bulgaria there are only partial analyzes of the individual elements of this complex system (Bachev 2020a, b, c, d; Bachev et al., 2014; Bachev and Mihailova, 2019 a, b; Bachev and Denchev, 1992; Bachev and Labonne, 2000; Bachev and Mihailova, $2019 \mathrm{a}, \mathrm{b})$. The reason for later is the lack of enough official statistics and other information as well as "sufficient" public interest in the development of this important system.

In our previous publications (Bachev 2020a, b, c, d; Bachev and Mihailova, 2019 a, b) a detailed analysis of some aspects of the development of AKIS in Bulgaria are presented including trends in evolution of AR\&D, agricultural training and consultation system, digitalization in agrarian sphere, etc. This paper gives insight on organization, financing and productivity of agricultural research in Bulgaria during the period after country's accession to EU in 2007. The analysis is predominately based on the research carried out in the Agricultural Academy-the main institutions responsible for the organization of agricultural research in the country. The goal is to specify major trends and identify main challenges, and assist policies formation during the next programming period. ${ }^{1}$

\section{The system of organization of Agrarian research in Bulgaria}

Agricultural and related research in Bulgaria is mostly carried out by public organizations_research institutes and experimental stations of the Agricultural Academy, some institutes of the Bulgarian Academy of Sciences (e.g., Institute of Plant Physiology and Genetics, Institute of Economic Studies, etc.), some of the public and private universities (e.g., Agrarian University in Plovdiv, Trasia University in Stara Zagora, Russe University in Russe, Forestry University in Sofia, University of National and World Economy in Sofia, High School for Agribusiness and Regional Development in Plovdiv, etc.), and to a smaller extent by the private firms and organizations, non-governmental organizations, etc.

There is no official (statistical, aggregated, etc.) information about the state and development of all components of this complex system, the relationships between different structures, and implemented specific forms of organization and cooperation in AR\&D.

The Agricultural Academy is a key element of the system for creating, sharing, disseminating and implementing knowledge and innovation in Bulgarian agriculture. Agriculture is the only branch of the economy for which an entire Academy $^{2}$ for scientific services, training and consulting has been built and publicly funded.

The analysis of the development of the staff of the Agricultural Academy, the organization and financing of its activity, its scientific and applied results, its relations with the other participants in AKIS, the main challenges to its development, etc. gives a good idea of the state of the main component of the national AKIS and the most general information about the state and trends in the development of the public sector of agricultural R\&D in the country.

According to the Law the present Agricultural Academy is a national autonomous budget organization for scientific research, for scientific-applied, innovative and educational activity in the field of agriculture and food (Decree of the Council of Ministers ${ }^{1} 151,25.06 .2018$ ). It consists of 29 scientific institutes and centers and 13 experimental stations (part of the State Enterprise "Research and Production Center") ${ }^{3}$, in the all main areas of agricultural research, and located in all regions of the country.

The scientific institutes and centers of the Agricultural Academy are specialized or complex and carry out R\&D in all main directions of agricultural research for servicing the agricultural production or its individual sub-sectors (Table 1). Experimental stations are specialized or complex for servicing agricultural production in a particular geographical area (region).

Some of the units of the Academy (Dobrudzha Agricultural Institute, Institute of Agriculture Ėàrnobat, etc.) manage significant land and other resources, while the material and technical base of the majority of the units is morally and physically obsolete. The average number of researchers in the institutes is just under 20, and at the experimental stations 2.5 (Agricultural Academy, 2018). The main part of the R\&D funding is on a project basis with the Agricultural Academy and other national and international organizations, from the sale of products and services, etc. The Agricultural Academy funding ${ }^{4}$ represents a different share of the total expenditues of the individual research units-from $20 \%$ for the Institute of Ornamental and Medicinal Plants to 94\% for the Agrobioinstitute (Agricultural Academy, 2018).

In fact, that analysis is being used for identifying public intervention needs and measures in the 2021-2027 Program for Agrarian and Rural Development of Bulgaria (Ivanov et al., 2020).

The Agricultural Academy (Selskostopanska akademiya) was established in 1961 and have been reorganised multiple times since then. This enterprise has proved to be highly inefficient and there is idea to (re)integrate this stations in the Research Institutes again. The major criteria for distribution of the Agricultural Academy support between different research institutes and stations has been the number of research personnel as budget subsidies de-facto covering the salaries and mandatory social payments of researchers and support stuff while (sales, competitive grants, areal-based subsidies from EU CAP, etc.) funding of other (material, supplementary activities, etc.) expenditures being responsibility of research unites. 
Table 1: List of scientific institutes and centers of the Agricultural Academy in Bulgaria

\begin{tabular}{|c|c|c|}
\hline \multicolumn{2}{|c|}{ Specialized units } & \multirow[t]{2}{*}{ Complex units } \\
\hline Subject principle & Industry-product $p$ & \\
\hline 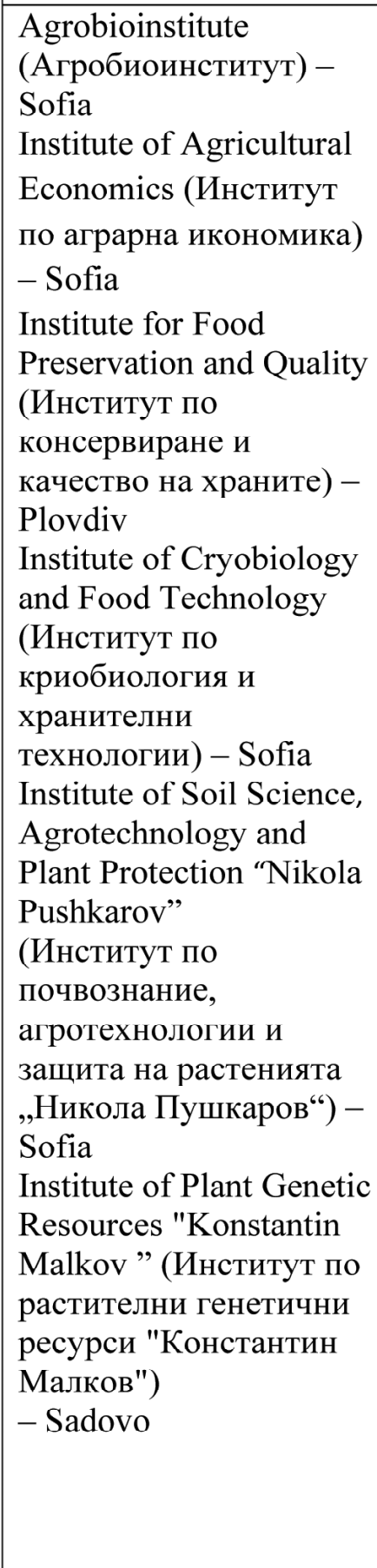 & 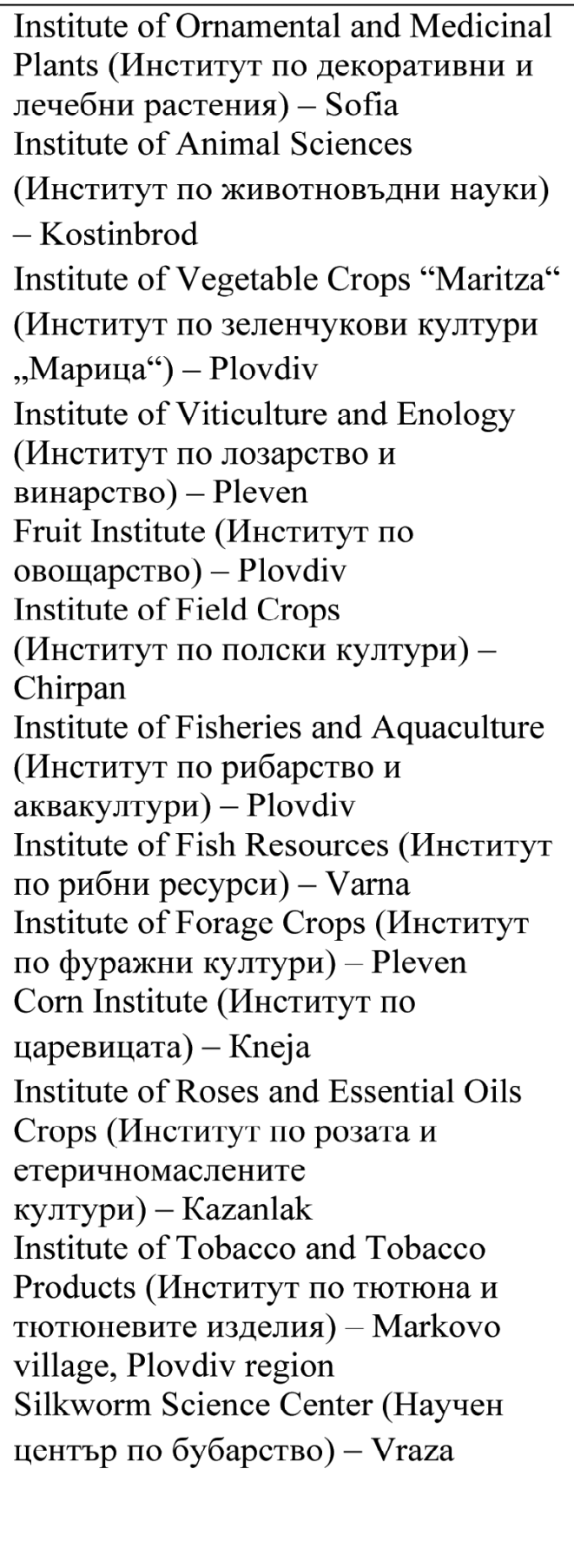 & 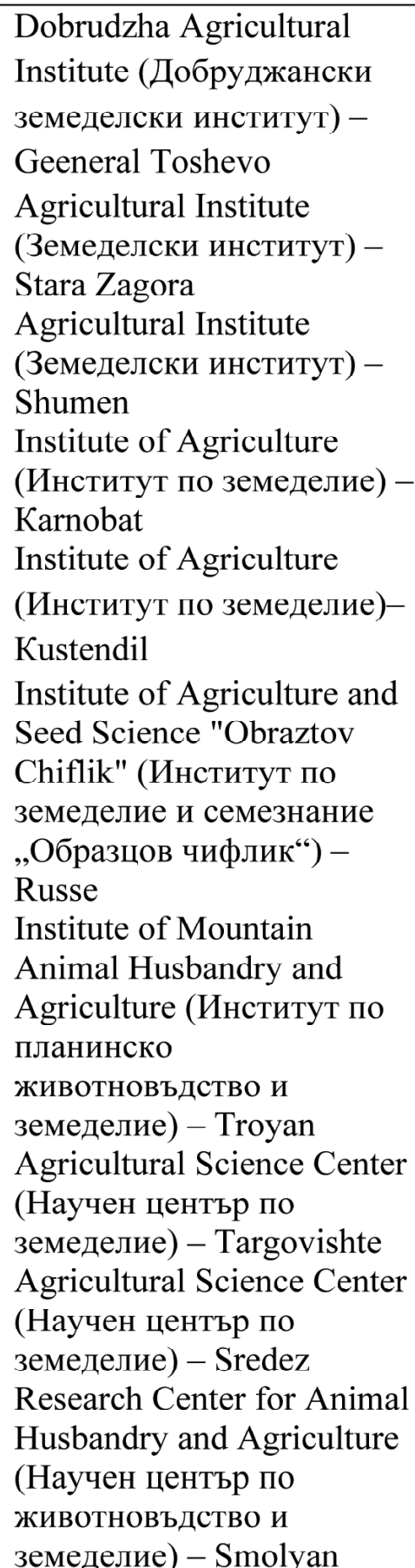 \\
\hline
\end{tabular}

Source: author, based on official regulation (Постановление на МС № 151, 25.06.20182.)

\section{Personnel endowment of the Agricultural Academy}

In the years after the country's accession to the EU, the number of researchers and experts employed in the Agricultural Academy has been constantly decreasing due to insufficient budget funding, regulatory constraints, restructuring and layoffs, lack of acceptable pay and working conditions, insufficiently qualified candidates in some areas, etc.

For 10 years, the average annual staffing in the Agricultural Academy decreased by $45 \%$ to 1890 , and the number of scientists by nearly $24 \%$ to 531 (Figure 1). At the same time, the structure of R\&D employees has been improving as the share of scientists increased to just over $28 \%$ of the total at the end of the period. This shows that along with the 
reduction of the staffing of the Agricultural Academy and the agricultural R\&D in the country as a whole, a progressive change has been taking place through a relative increase in the share of the active and highly qualified staff.

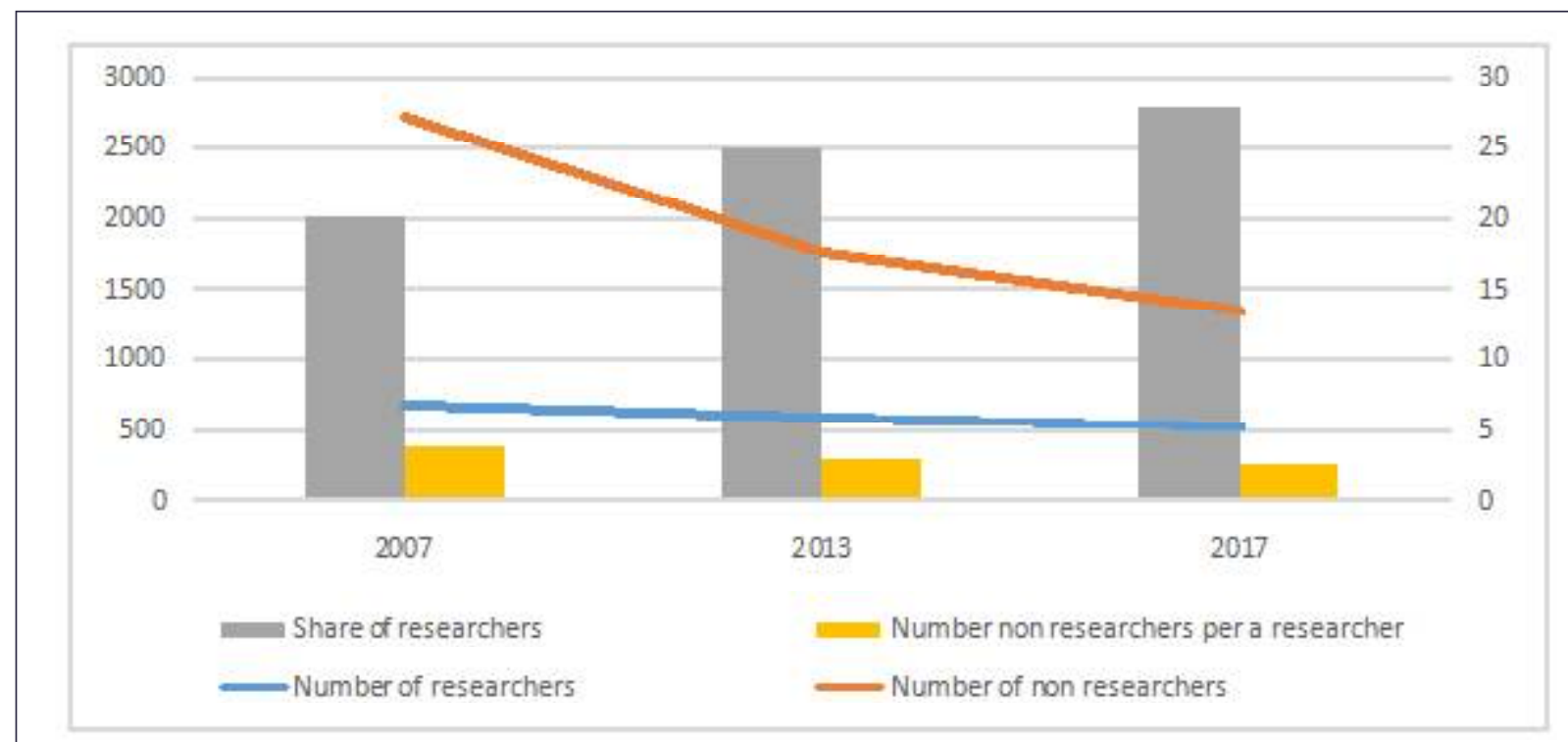

Figure 1: Number and ratio of scientists and other full-time staff of the Agricultural Academy in Bulgaria (number, \%)

Source: Annual Reports of the Agricultural Academy

Throughout the period, the habilitated staff of the Academy (Professors and Associate professors) makes up a little over half of all scientists, and doctors (PhD) and doctors of science (DS) are over 70\% and increasing in recent years to almost $80 \%$ (in 2017). This shows that the qualification structure of staff composition is very good and adequate to meet the modern challenges of science and practice.

At the same time, however, there are unfavorable trends in the development of the age structure of researchers at the Academy. Although the average age increased slightly during the period (from 48.4 in 2007 to 49 in 2017), the share of young scientists decreased relatively, at the expense of an increase in those over 60 (Figure 2). The main reason for this

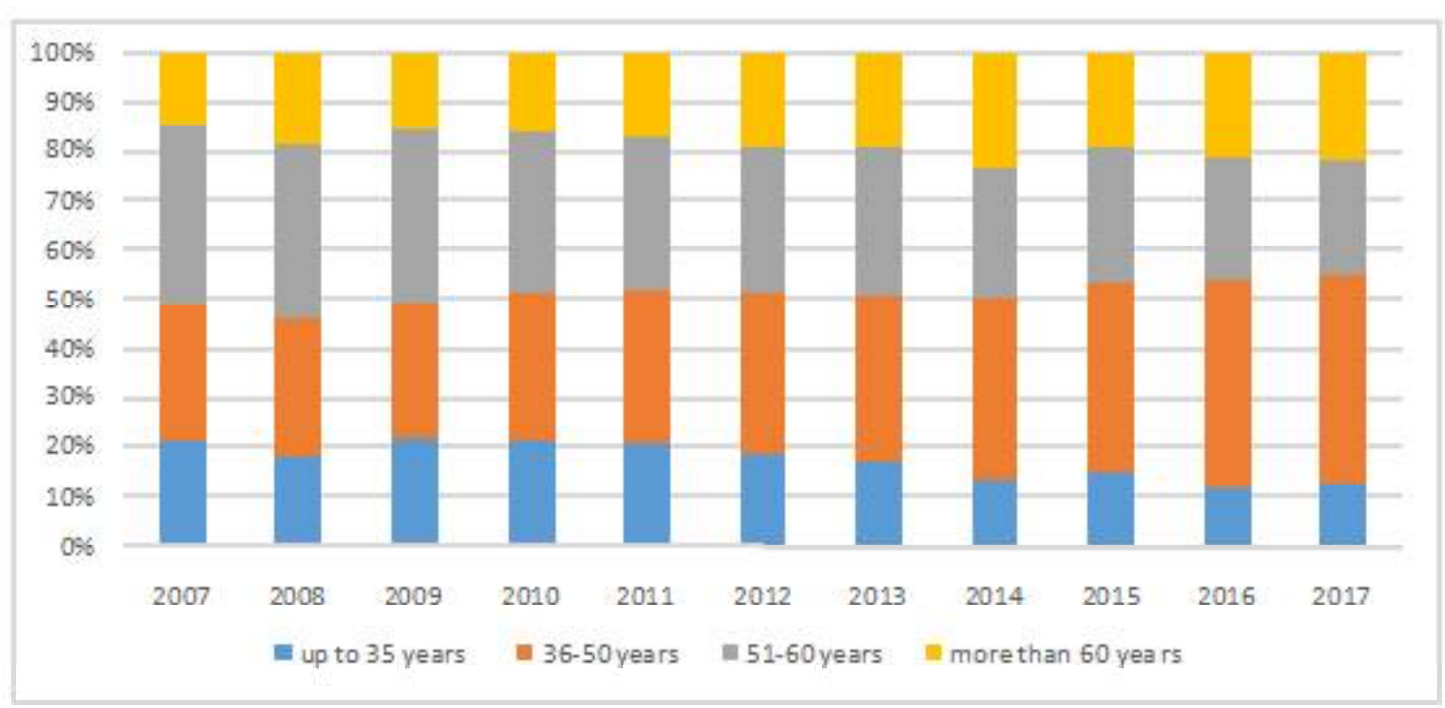

Figure 2: Age structure of researchers of the Agricultural Academy in Bulgaria 
is the lack of enough young candidates ready to pursue a career in science, due to lower pay compared to private business, public institutions or foreign academic and other organizations. If this trend continues, the Agricultural Academy will have serious problems in the near future in securing the needed qualified staff to carry out its mission and research program.

\section{Funding of activity of the Agricultural Academy}

The budgetary "institutional" support of the Agricultural Academy is essential for the R\&D activity of research institutes and centers (Activity 163). It is distributed mainly on a "project" basis, in which teams from the Academy units make proposals for research projects, which, after evaluation by specialized Expert Councils, are approved by the management of the Academy.

The main research priorities in the Agricultural Academy are four and are in line with the national and European priorities in this area:

- Sustainable development of competitive knowledge-based agriculture;

- Preservation of natural and genetic resources to mitigate the impact of climate change;

- Safe, quality and healthy agricultural raw materials and food; and

- Improving the quality of life in rural areas through competitive agriculture and increasing incomes.

In the Agricultural Academy are carried out projects under eight scientific programs:

1. Collection, research, storage and management of plant genetic resources. Improving the varietal composition of the main agricultural crops and production of quality pre-basic and basic seeds and planting material.

2. Comprehensive ecological and economic assessment of soil resources and new technologies to increase soil productivity.

3. Problems related to the resilience and tolerance of agricultural crops to water deficit and extreme temperature effects of the environment. Optimization of irrigation techniques and technologies in the conditions of water deficit.

4. Technologies for organic production of plant and animal products. Development of integrated plant protection systems as a basis for safe food production and ecosystem protection.

5. New economically and energy efficient technologies for competitive production of plant and animal products that meet EU requirements.

6. Systems for storage of the national gene pool and creation of highly productive breeds and lines of farm animals for production of animal products, meeting EU standards. New feed sources and feed additives.

7. New methods and technologies for production and storage of safe food, beverages and organic products. Extending the period for supplying the domestic market with fresh fruit and vegetables.

8. Assessment of the agro-ecological potential of the agricultural regions and diversification of the agricultural production. Development of organizational and economic structures in farming and their improvement. Socioeconomic problems of rural development.

In addition to the direct subsidies from the state budget (until 2018 from the Ministry of Agriculture, and since then from the Ministry of Finance), the Agricultural Academy units receive budget funds for R\&D from other public institutions (Ministry of Education and Science, Ministry of Waters and Environment, etc.) mainly on a project basis. The Agricultural Academy also receives significant budgetary resources under other national and European programs - Human Resources Development, Program for Rural Development and direct payments based on utilized agricultural area, defense and mobilization preparedness, etc. A good portion of all these funds is practically used for the maintenance of scientific units and R\&D activity.

For the analyzed period, there is a significant reduction in total expenditures and budget subsidies for research institutes and centers of the Academy (Figure 3).

The level of expenditures in 2015 was almost $36 \%$ lower than in 2007, after which there was a significant increase in expenditures and activity below the levels at the beginning of the period. The decrease in the budget expenditures has been relatively smaller than the overall decrease in expenditures, which demonstrates the growing importance of the budget financing of the activity during the period. 


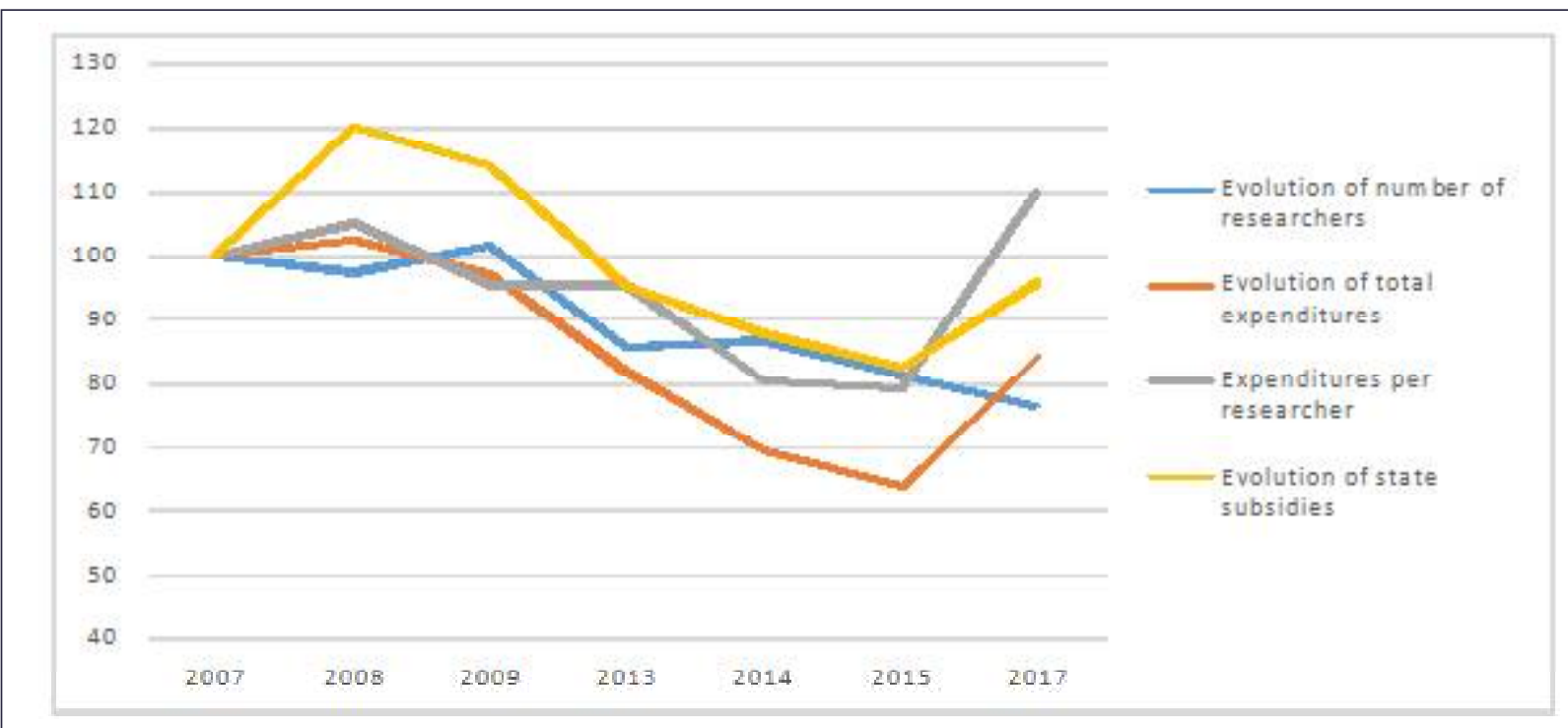

Figure 3: Evolution of the general and budgetary financial endowment of scientists of the Agricultural Academy in Bulgaria (2007=100)

Source: Annual Reports of the Agricultural Academy

Despite the reduction in the total number of scientists, the financial and material endowment per scientist decreased after 2007 by $20 \%$ (2015), after which it increased at the end of the period by almost $10 \%$ above the initial level (Figures 3 and 4). During the period, the size of the budget expenditures per one scientist fluctuates significantly in levels above the base one, and in 2017 their size is with a quarter higher than in 2007.

This confirms the crucial role of the budget funding for maintaining and increasing the provision of researchers with salaries, social insurance, material resources, etc. This is accompanied by a stronger orientation of the overall R\&D towards the strategic state priorities (the financing organization) rather than towards the immediate needs of the market and the end users of knowledge and innovation.

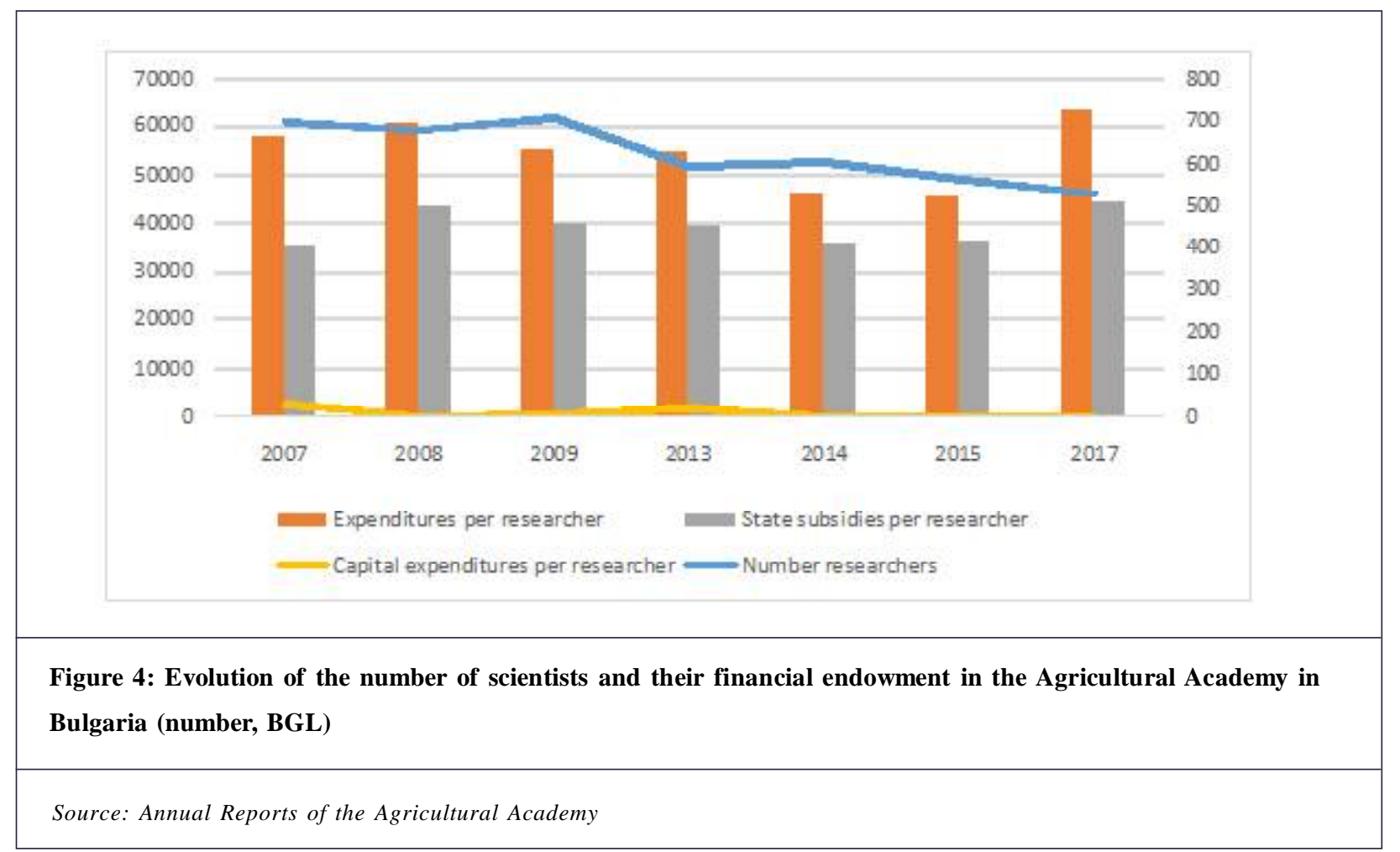


However, the capital expenditures for R\&D during the period are insignificant in size, carried out only in individual years and with a decreasing amount per scientist. Their maximum share in the total costs is a little over $4 \%$ in the first two years of the period, while in the last few years it is negligible or zero. The later deters modernization of the material and technical base and the resource endowment of scientists and reduces the efficiency of R\&D.

Own generated revenues account for $21-38 \%$ of the total expenditures for research institutes and centers the Agricultural Academy in individual years, and their size varies greatly and decreases over the period (Figure 5). The sale of services, goods and products is the main source of R\&D revenue (almost 100\%) and gives an idea of the degree of market orientation and commercialization of the activity, and the practical dissemination and implementation of the results of the research activity. In 2017, the own revenues (sales, rents, donations, etc.) from the country finance $30 \%$ of all R\&D expenditures of the Academy.

The total amount of income from own activities and the amount of income per scientist decreased significantly by 2015 (by three quarters and 57\% respectively) and reached $86 \%$ of the initial level in 2017 . This is an indicator that the importance of market orientation and funding in the management of the activity, and of direct relations with consumers of knowledge and innovation, relatively decreased during the period.

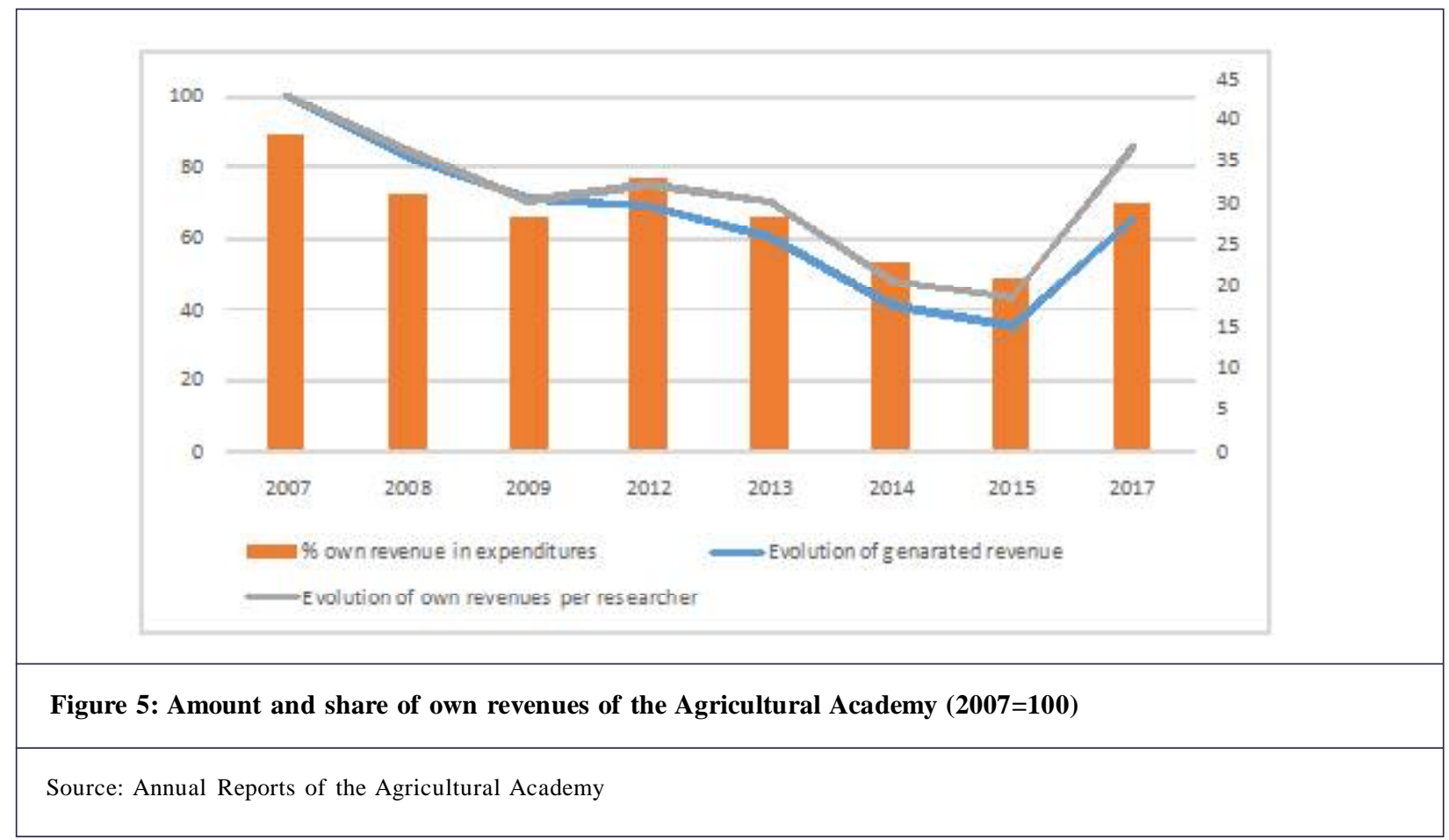

The Agricultural Academy also receives funds from international programs and agreements, donations and grants from abroad, revenues from sales of products, goods and services abroad, etc. In some years, their level varies widely and decreases in recent years, as they account for a different share of the total own revenues of the Academy-from $0.2 \%$ (2017) to $18 \%$ (2008) (Figure 6).

The amount of this source of funding is almost entirely formed by grants, donations and other grants received as well as sales of services, goods and products, which have different significance in the individual years. The size, dynamics and share of the international programs and markets for intellectual property and sharing of scientific knowledge gives an idea of the degree of inclusion of the Agricultural Academy in the international division and cooperation of labor in the generation, transfer and dissemination of knowledge and innovation.

\section{Production and Productivity of the Agricultural Academy}

Research units and teams of the Agricultural Academy work on a large number of research projects funded by the Agricultural Academy, Ministry of Education and Science and other national agencies and organizations (Figure 7). Projects are a form of organization of research and cooperation of researchers and stakeholders from different fields and disciplines, and often organizations (institutes of Agricultural Academy, Bulgarian Academy of Sciences, Medical Academy, universities, National Agricultural Advisory Service, farmers and farmers' organizations, etc.). 


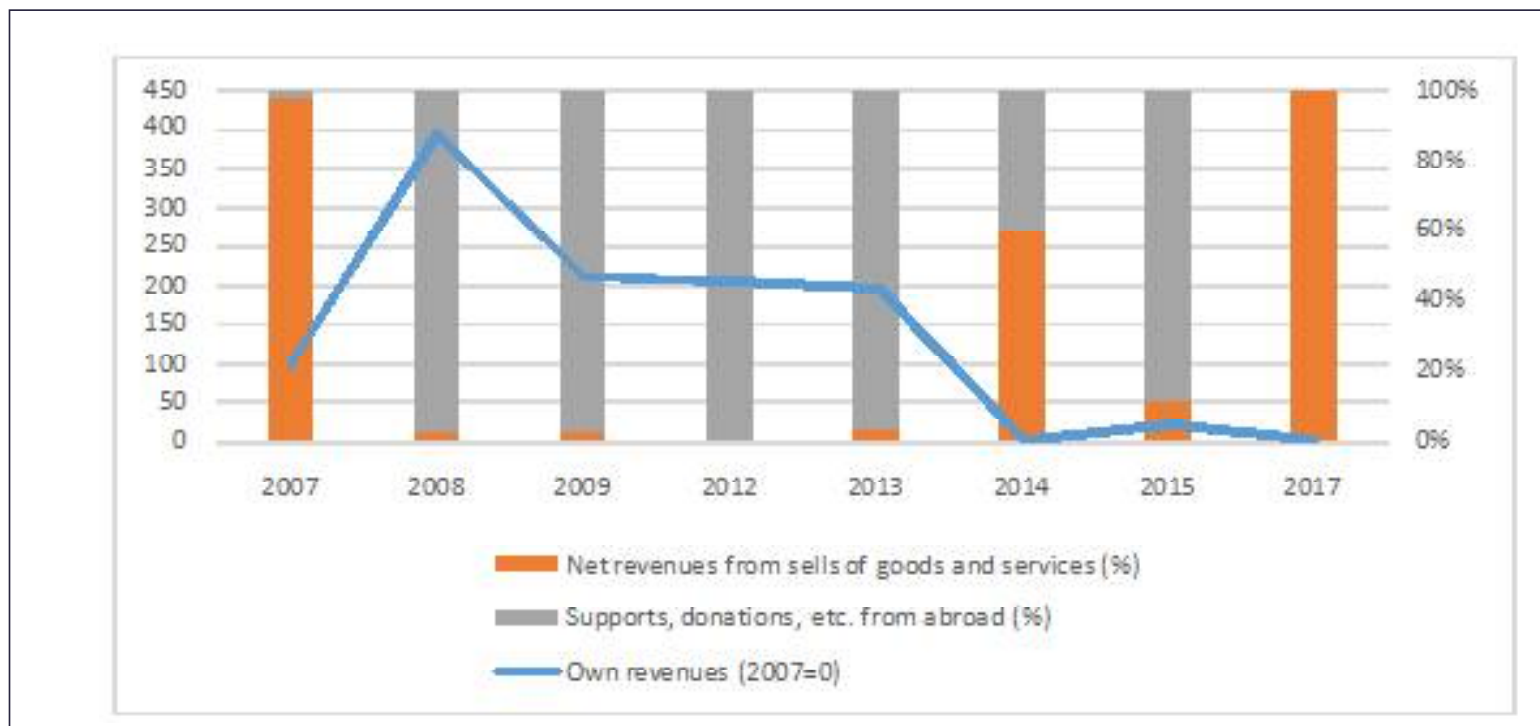

Figure 6: Level and share of own revenues from international programs and agreements, donations and grants from abroad, and sales of products, goods and services of the Agricultural Academy in Bulgaria

Source: Annual Reports of the Agricultural Academy

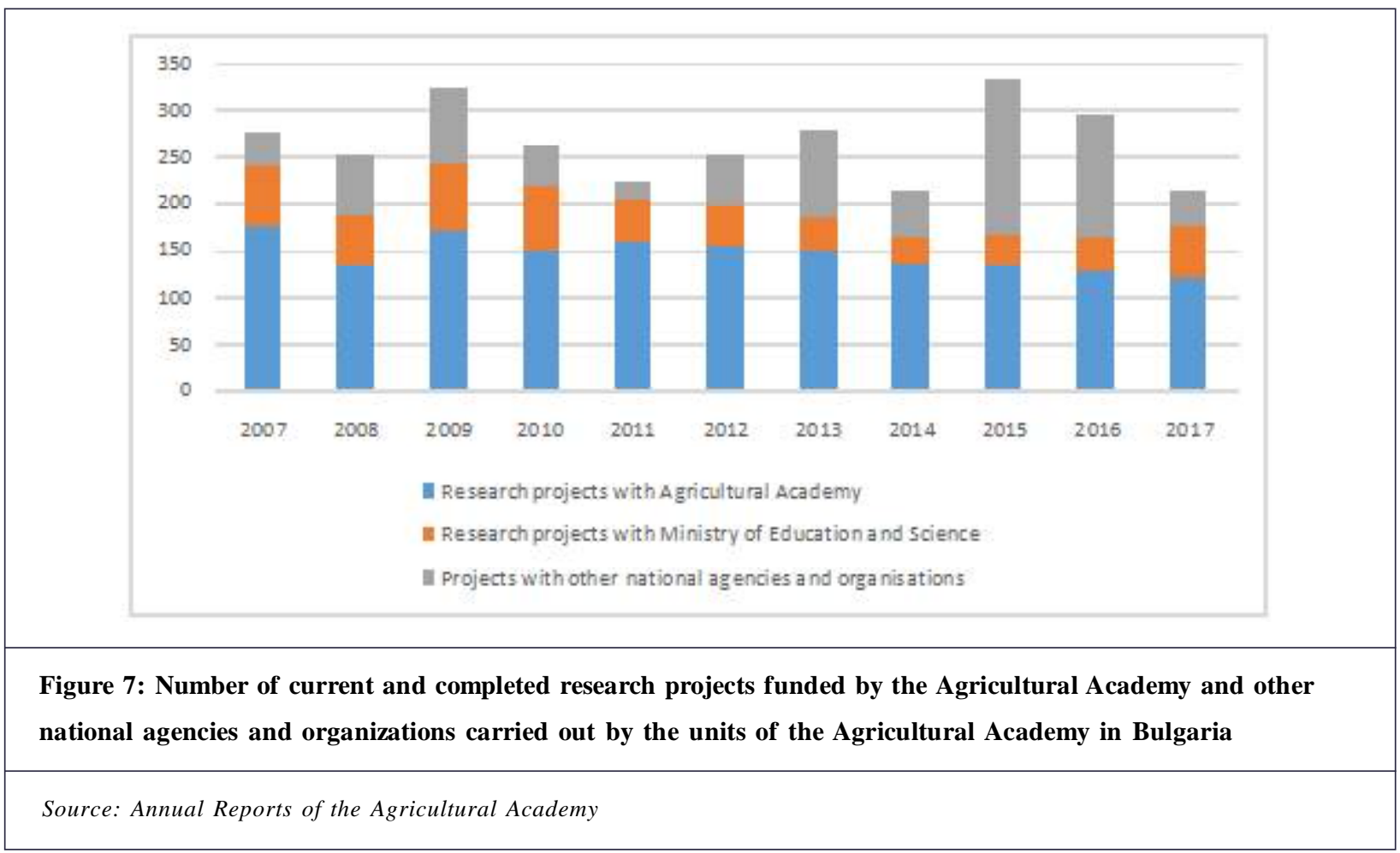

The total number of national projects varies from year to year, and for most of the period the share of the Agricultural Academy projects predominates. In 2015-2016, the projects funded by foreign agencies and organizations are more. The later demonstrates higher activity in the preparation and winning of projects on a competitive basis and the efficiency of participation in the "national market" for research projects.

In addition, the Agricultural Academy teams work on a significant number of bilateral and multilateral international projects, which in different years represent from 34.5\% (2015) to 46.4\% (2014) of the total number of projects. Moreover, most international projects are multilateral-from $27.2 \%$ (2014) to 35\% (2009) of all of them. These data are an expression of the active involvement of the Agricultural Academy in international cooperation for the joint generation, transfer and dissemination of knowledge and innovation. 
The number of carried out projects funded by the Agricultural Academy and the Ministry of Education and Science decreased during the period, while the number of projects contracted with other national agencies and organizations varied widely (Figure 8). This is accompanied by an increase in the national projects implemented by one scientist from 0.4 to 0.6 . The number of carried international projects throughout the period is higher than in 2007 and relatively stable, together with an increase in the number of projects (productivity) per scientist-from 0.2 to 0.3 .

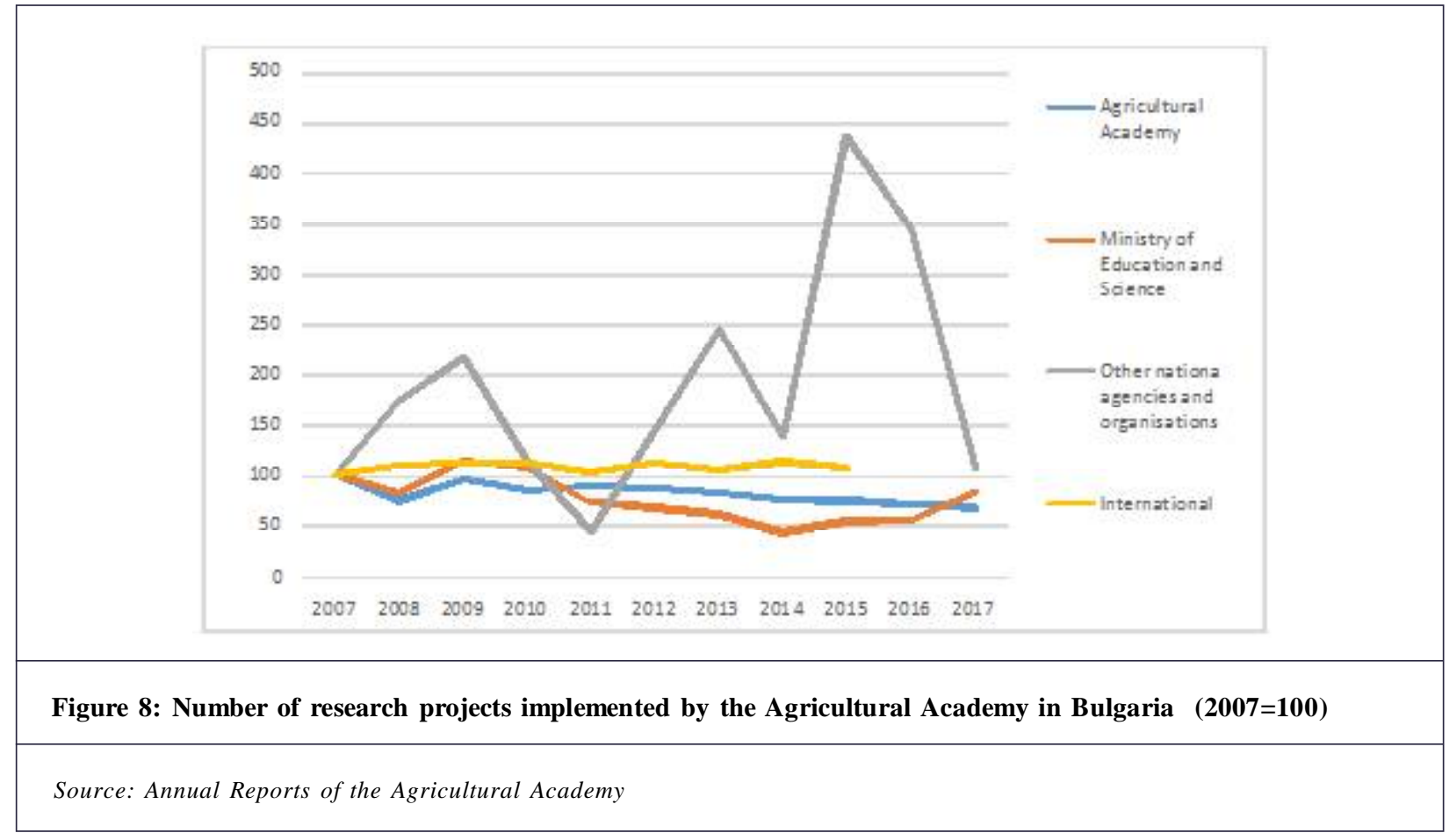

Along with the research activity, the Agricultural Academy also trains doctoral students in the field of agricultural sciences, for the needs of the Academy and other state and private organizations. Doctoral studies are on current issues of science and practice, which are integrated into the programs of scientific units, which increase both the efficiency of training and the effectiveness of the work of the Agricultural Academy.

Throughout the period there is a tendency to increase the number of successfully defended dissertations. By 2015, the total number of doctoral students is increasing, which has decreased in the last two years (Figure 9). At the same

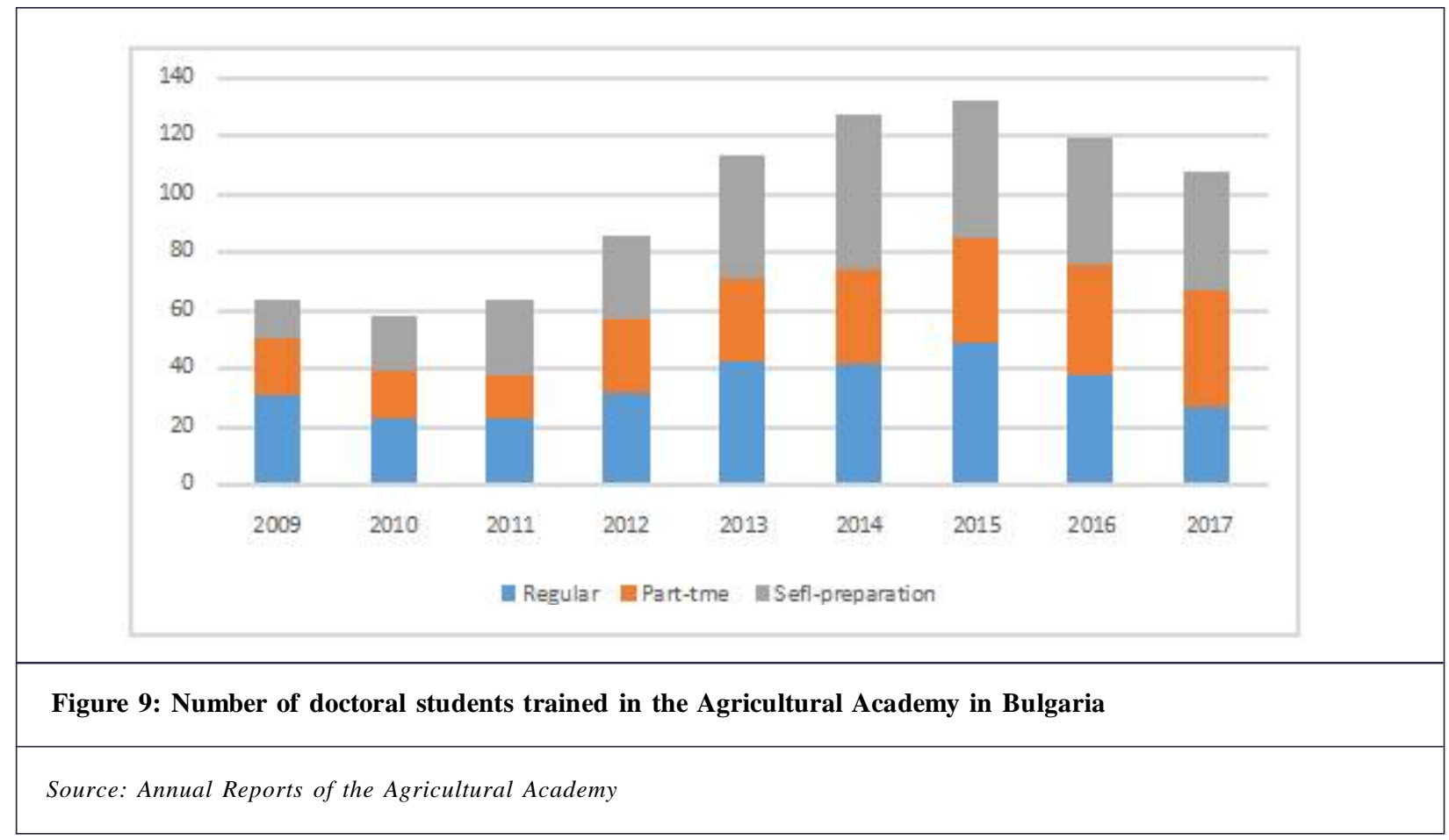


time, the relative share of full-time doctoral students' decreases and that of part-time and self-study increases. The latter groups include researchers and experts in the Agricultural Academy units and other public and private organizations. All this shows that the role of the Academy in training highly qualified specialists for the needs of scientific and other organizations in the country has been increasing.

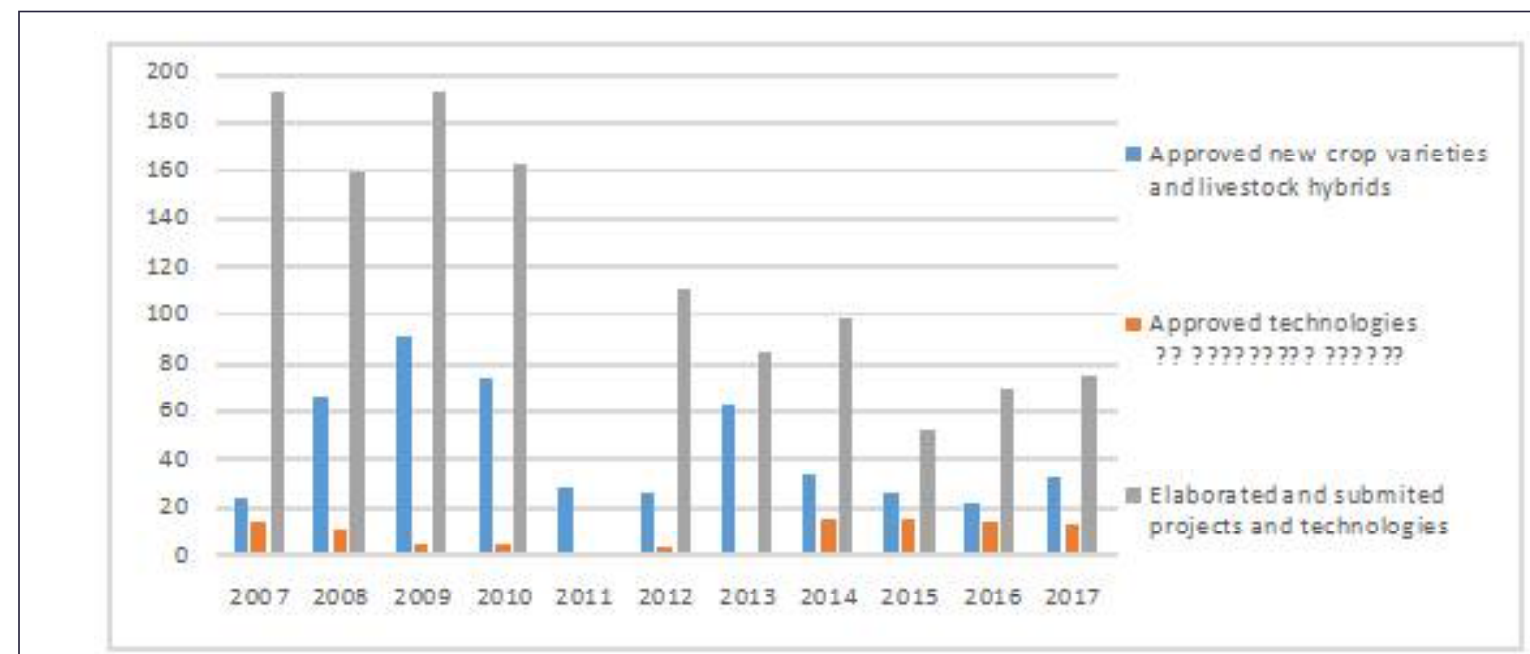

Figure 10: Number of officially approved new varieties and hybrids of plants, animal breeds and works, and approved technologies from the Agricultural Academy in Bulgaria

Source: Annual Reports of the Agricultural Academy

As a result of the R\&D of the Agricultural Academy, a large number of new scientific products are created, which after approval (certification, etc.) by the relevant institutions are provided for implementation in practice through direct transfer, contracts and licensing agreements with the private sector and others.

The number of approved new varieties and hybrids of plants, as well as animal breeds, established technologies and works, and presented projects and technologies are significant during the period (Figure 10). The variations in the amount of scientific production in the individual years arise from the nature of the R\&D performance (long period of creation and formalities for approval of varieties and breeds, uncertainty, cyclicity, etc.)

The Agricultural Academy maintains 350 certificates of protected products issued by the Patent Office, including the largest number (about $85 \%$ ) of all issued and maintained certificates for plant varieties and animal breeds. Of these, the largest share is of cereals (151); beans (7); oilseeds and industrial crops (39); fourages (30); vegetables (48); tobacco (22); vines (22); fruit (2); breeds of animals (14) and flowers (15). In addition, 12 technologies and instructions for production, and processing of tobacco are included; as well as oil rose picking machine; 2 useful models in cryobiology and food technologies; device for express diagnosis of the degree of infestation of bee families with varroasis, etc.

The official variety list of the country includes a total of 285 varieties of the Agricultural Academy, as in list A (cereals, fodder, oilseeds and industrial crops, beets, potatoes and fruit plants) are included 226 varieties, and in list B (vegetable, ornamental, medicinal and aromatic crops and vines) 59 varieties (Agrarian Report, 2018).

New scientific products often outperform old ones and are quickly implemented in practice. The possibility to register rights and grant licenses creates an economic incentive to increase the efficiency and commercialization of intellectual agricultural products. However, in the country there is no official information and reliable methods for establishing the degree of implementation of the developed new varieties and hybrids of plants, animal breeds and technologies due to lack of effective regulations or willingness to sanction intellectual property rights, mass piracy of varieties, impossibility of effective control and insufficient incentives and sanctions, etc. For example, in 2017, out of the total number of Agricultural Academy certificates (350), only 19.7\% have concluded license agreements. All this slows down the commercialization of intellectual agricultural property and market management of R\&D in the country.

\section{Dissemination of research output of the Agricultural Academy}

The Agricultural Academy and its units use a variety of forms to disseminate and share knowledge, provide scientific services and support innovation in agriculture. 
Publishing in the publications of the Agricultural Academy and its units (magazines, books, collections, brochures, etc.) and in other national and international academic and scientific-applied publications are the main channel for dissemination of the results of scientific and scientific-applied activities of the Academy.

The number of different types of publications during the period is huge and evidence of the high productivity of researchers (Figure 11). There is a tendency to increase the number of publications in prestigious magazines with an impact factor and in foreign magazines. This is an indicator of the international recognition of the Academy's R\&D performance and the growing contribution to the global sharing of knowledge and scientific development.

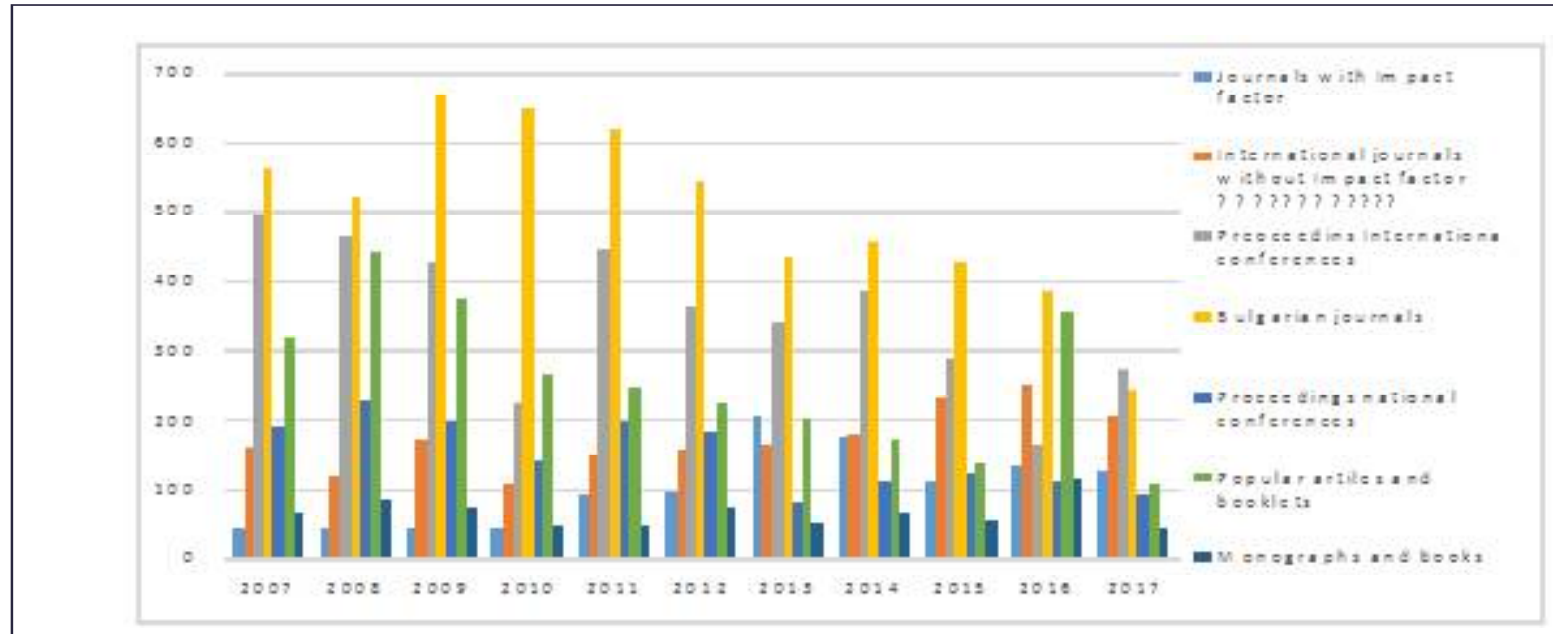

Figure 11: Number of publications of the Agricultural Academy in scientific and popular science magazines, brochures, proceedings and books

Source: Annual Reports of the Agricultural Academy

One of the most popular and widely used forms for sharing and disseminating knowledge and supporting innovation in agriculture are holding open days for farmers and stakeholders, creating demonstration fields, farms, etc., organizing scientific and practical conferences, seminars, symposia, round tables, anniversary celebrations, etc., and conducting short-term training courses. During the different years of the period, a large number of all these forms take place in the Agricultural Academy units, with the participation of many farmers of different types and other stakeholders (Figure 12).

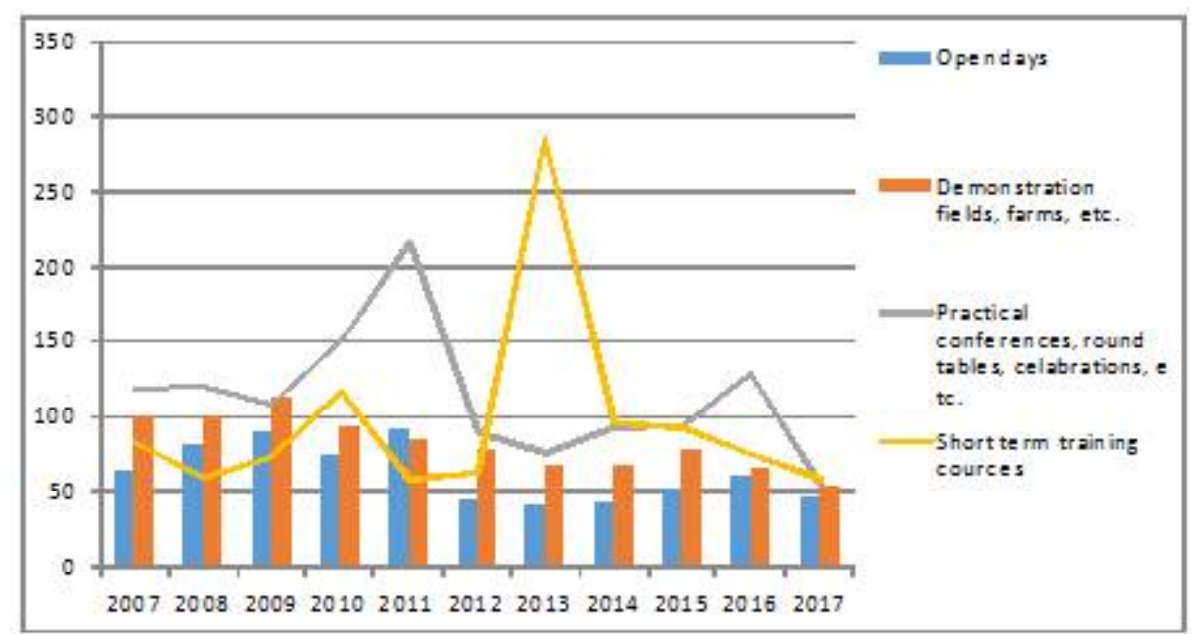

Figure 12: Number of created demonstration fields, open days, scientific-practical conferences and short-term courses from the Agricultural Academy in Bulgaria 
After the country's accession to the EU, the Agricultural Academy's participation in the training of farmers and specialists of various types has improved. For example, during the period 2011-2015 in the Center for Vocational Training and in the scientific institutes of Agricultural Academy 2203 agricultural producers and specialists were trained, including 46\% under Measure 111 in the specialties animal husbandry, plant growing, ecology, perennials, etc. (Agricultural Academy). In 2017 alone, 265 agricultural producers were trained in the courses of the Center for Vocational Training in the professional fields "Farmer", "Agroecologist", "Livestock Breeder" and "Plant Technician". Trainings were also conducted for over 100 people under Ordinance 2 of 23.07.2017 on the specific requirements for production, collection, transportation and processing of raw milk, the marketing of dairy products and their official control and for the purposes of self-control.

In addition, Agricultural Academy research units and experts participate in many joint training and dissemination initiatives with other organizations such as National Agricultural Advisory Service, universities, private and professional organizations, and others.

Other effective forms for popularizing the scientific achievements of the Agricultural Academy and disseminating knowledge are participation in exhibitions and fairs at home and abroad, participation in national, regional and local radio and television programs, as well as publications in the press. The use of modern media such as radio and television has tended to increase over the period, enabling to reach many users at low-cost.

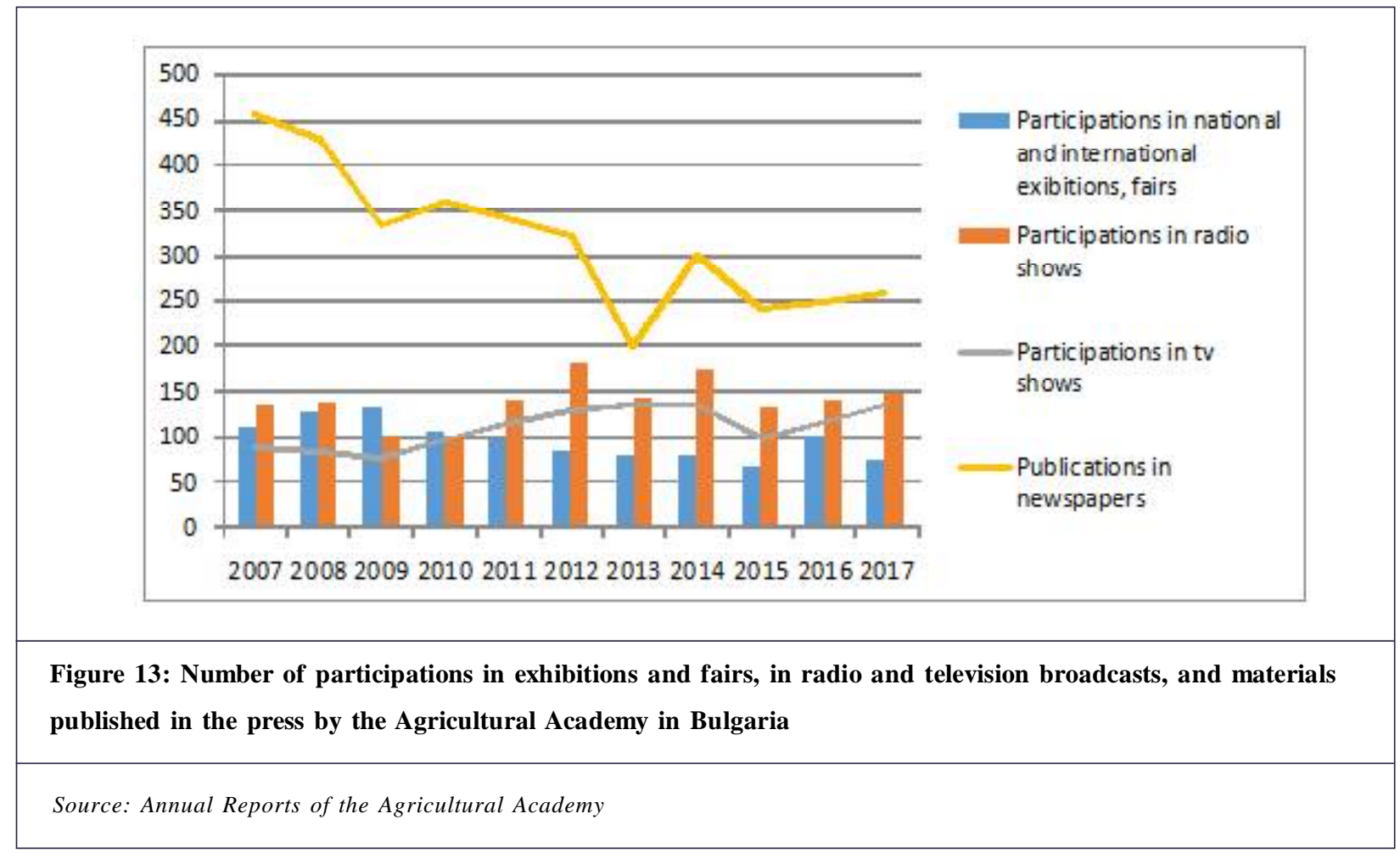

Also, Agricultural Academy researchers take an active part in the development of many official documents (standards, norms, laws), opinions for farmers, cooperatives and agencies, advertising materials (brochures, newsletters, leaflets, videos, etc.) and in lecturing and reporting. The growth of this type of activity shows that the diverse expertise of the Agricultural Academy is widely sought after by various agents making management decisions at different levels and all stakeholders.

The dynamics of all these indicators gives an idea of the changing possibilities (qualification, financial and organizational capacity) for organizing and participating in such forms, the efficiency and complementarity of the individual forms, as well as the adaptation to different needs (demand) of various participants in the system for sharing knowledge and innovations in the country.

In addition to all this, the Agricultural Academy performs other important functions related to the scientific service of the industry, such as maintenance of plant and animal gene pool, performed analyzes of soil, plant and animal products, information services, independent expertise, etc. In this way, it contributes to improving the scientific and technical level in the agriculture, preserving the "accumulated" biological potential, as well as disseminating knowledge and innovation in the sector. 


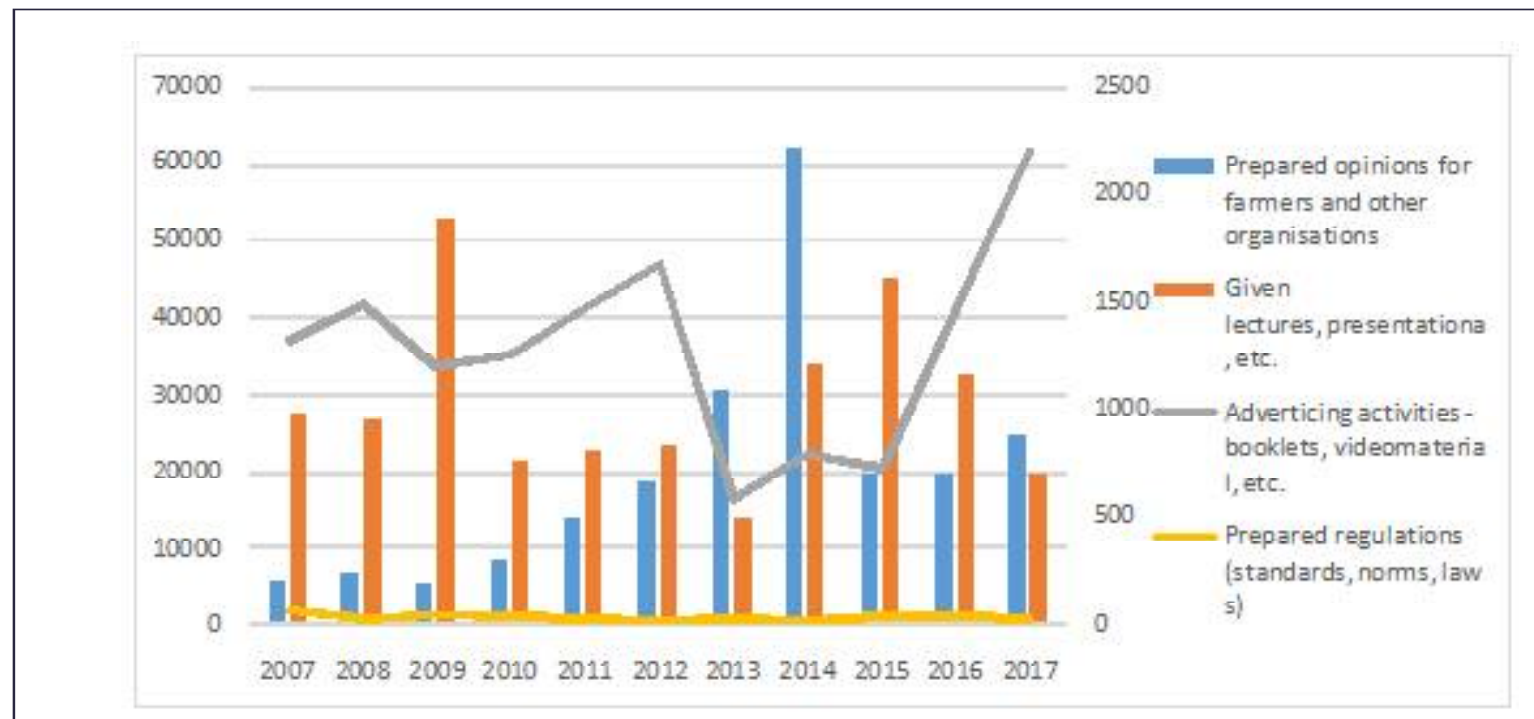

Figure 14: Number of prepared opinions for farmers, cooperatives and agencies, developed official documents, delivered lectures, reports and advertisements from the Agricultural Academy in Bulgaria

Source: Annual Reports of the Agricultural Academy

Over the last three decades, various "reforms" of the country's agricultural research system, and in particular the Agricultural Academy, have been undertaken. However, despite certain success in some areas in recent years, still there is not established an effective structure for the organization of R\&D, and systems for public funding of activities, coordination and evaluation of research, evaluation and incentives for researchers and teams, as well as protection of intellectual agricultural property. Some of the research institutes and centers do not have or are on the border of the "critical" mass of human, financial and material resources necessary for effective conducting of modern research Institute of Roses and Essential Oils Crops (6), Institute of Fisheries and Aquaculture (7), Institute of Ornamental and Medicinal Plants (9), Institute of Fish Resources (9), etc. The organizational separation of the experimental stations, on the other hand, does not allow the effective integration of their "significant" resources in the R\&D coordinated by the scientific institutes and centers.

All this does not allow to fully realize the great potential of the Agricultural Academy improve the scientific and technological level of the agricultural sector in the country.

\section{State of Agrarian Research Conducted in other Organizations}

The general tendencies, efficiency and problems in the development of the agrarian researches in the universities and Bulgarian Academy of Sciences are similar to those in the Agricultural Academy. Many of the universities traditionally have no strong research programs due to lack of researchers' time, financial and material resources, sufficient capacity to win and implement projects, etc.

Universities receive insignificant subsidies from the Ministry of Education and Science for "internal" projects, which are usually "fundamental", small in size and include part of the academic staff. In recent years, additional weight has been given to the distribution of the state subsidies according to science-metric indicators, on which only few universities have comparative advantages mostly outside of "agrarian" programs. In addition, universities compete for funding from research programs of the National Science Fund of the Ministry of Education and Science and other national and international organizations, make contractual research for business and other organizations.

In 2017 the share of the budget for funding from National Science Fund projects in "Agricultural Sciences" was 17\%, which is extremely insufficient (REPORT of the Commission for Monitoring, Evaluation and Analysis of the activities of the Research Fund at the Ministry of Education and Science, 2018). Moreover, the share of public higher education institutions in the total funding of the National Science Fund was only $42 \%$, which shows that only part of the projects in "Agricultural Sciences" are in universities. 
The financing of agricultural research in the country by the European programs such as FP7, HORIZON 2020 and others is also insignificant. The total funding of Bulgarian science from these funds is significant, nevertheless among the lowest in Europe-for example, funding from HORIZON 2020 for Bulgarian organizations is "significant" (105.5 million Euros), but only $0.25 \%$ of the total budget of that program, the number of participants from Bulgaria is $0.58 \%$ of all, with only one leading organization from the country, etc. (HORIZON 2020). At the same time, in the ten most active organizations in the country for winning projects from the main EU programs such as FP7 and HORIZON 2020, there is none in the agricultural field.

The main universities in which research in the field of agriculture and food technology is carried out are: the Agricultural University, Plovdiv; Thracian University, Stara Zagora; University of Forestry, Sofia; University of Food Technology, Plovdiv; and University of Ruse, Ruse. In recent years, other "non-specialized" in the field of agriculture universities and institutes of the Bulgarian Academy of Sciences are also quite competitive to enter the field of agricultural and related research such as bioeconomics, food security, ecology, AKIS, socioeconomic and other projects.

There is no aggregated information in the country about the nature and volume of agricultural research conducted by Bulgarian universities. The situation is similar with the available information on agricultural research in the institutes of the Bulgarian Academy of Sciences, given the more fundamental and multidisciplinary nature and the diverse goals of research that often go beyond the agricultural field. It is also difficult to find information on agricultural research carried out in the private sector. All this hinders the analysis and management of AKIS in the country and requires the collection of similar information in the future.

The conclusion in the RDP 2014-2020 is also relevant for the agricultural universities and the Bulgarian Academy of Sciences: "the provision of consulting services and knowledge transfer in the country are not systemic. The results of research, such as innovations for introduction into agricultural holdings, are presented mainly at academic conferences or exhibitions without being promoted among potential users. The Agricultural Academy, due to its limited budget, presents results only on demonstration fields. On the other hand, research topics, although they generally cover key problems in agriculture, are not linked to the specific problems of specific farms or specific sectors".

In Bulgaria there is no summary information on the degree of implementation of different types of innovations in agriculture. There are good examples of implemented science and technology achievements in all sub-sectors. These innovations are implemented by innovative entrepreneurs who manage to study, transfer and adapt the highest achievements in the respective field, providing the necessary organization, financing, consulting and know-how in a private way. However, the overall level of innovation implementation in the country is far below the world and EU level, with significant differences in the technological level of the "leading" farms and the average level in most holdings of the country.

Our 2019 survey among farmers' organizations and innovative farmers found that there is not enough information about the achievements and "ready" innovations of the institutes of Agricltural Academy, Bulgarian Academy of Sciences and universities. Moreover, the majority of the implemented innovations in the country are "imported" from abroad, due to the lack of effective solutions in the local institutes and universities for the contemporary needs and actual conditions of the Bulgarian economies.

\section{Conclusion}

Agriculture is the only branch of the economy for which a special structure for scientific services has been built and publicly funded-Agricultural Academy. Some of the Academy units manage significant land and other resources, but the material and technical endowments of the majority of them is outdated, while some have no "critical" mass of human, financial and material resources needed for carrying effective modern research. The number of researchers and experts employed in the Academy is constantly decreasing due to insufficient budget funding, regulatory constraints, restructuring and layoffs, lack of acceptable pay and working conditions, insufficiently qualified candidates in some areas, etc. Since joining the country to the EU, there has been a significant reduction in overall expenditure and budget subsidies for agrarian research institutes and centers. Despite multiple "reforms" of the agrarian research system, the country still does not have an effective structure for organization of R\&D and public funding systems, coordination and evaluation of research, evaluation and stimulation of researchers and teams, and protection of intellectual agricultural property rights. The trends and problems in the development of agricultural research in universities and Bulgarian Academy of Sciences are similar to those in the Agricultural Academy. However, there is no aggregated information about the nature and volume of agricultural research conducted by the Bulgarian universities, institutes of the Bulgarian Academy of Sciences, and in the private sector. All this requires the collection of similar information in the future in order to improve analysis and management of AKIS. 


\section{References}

Agricultural Academy (2018). Anual Report of Agricultural Academy, Sofia.

Agrarian Report (2018). Agrarian Report, MAF.

Anandajayasekeram, P. and Gebremedhin, B.(2009). Integrating innovation systems perspective and value chain analysis in agricultural research for development: Implications and challenges. Improving Productivity and Market Success (IPMS) of Ethiopian Farmers Project Working Paper 16, International Livestock Research Institute, Nairobi.

Antle, J., Jones, J. and Rosenzweigc, C. (2017). Next generation agricultural system data, models and knowledge products: Introduction.Agricultural Systems. 155, 186-190.

Bachev, H. (2013). Risk management in the agri-food sector.Contemporary Economics. 7 (1), 45-62.

Bachev, H. (2020a). Diagnosis of the system for sharing knowledge, innovation and digitalization in agriculture (AKIS) in Bulgaria.Journal of Integrated Marketing Communications and Digital Marketing,1(1), 1-17.

Bachev, H. (2020b). State and needs of agricultural knowledge and innovation system in Bulgaria. Proceedings $3^{\text {rd }}$ International Scientific Conference, Technology Transfer: Innovative Solutions in Social Sciences and Humanities, 32-36, Talin, April 30, 2020.

Bachev, H. (2020c). A study on development of agrarian research and innovation system in Bulgaria, Sumerianz.Journal of Economics and Finance. 3(3), 11-23.

Bachev, H. (2020d). State and evolution of public and private research and development in Bulgarian agriculture.International Journal of Sustainable Development \& World Policy. 9(1), 10-25.

Bachev, H. and Mihailova, M. (2019). State and evolution of agrarian research and development in Bulgaria, Bulgarian Journal of Agricultural Economics and Management. 3, 3-22.

Bachev, H. and Mihailova, M. (2019). State, efficiency, and factors of development of the system of knowledge sharing, innovation and digitalization in agriculture.Bulgarian Journal of Agricultural Economics and Management. 4, $3-23$.

Chartier, O., Doghmi, M.,Fourcin,C.,Broek, M. and Midmore,P. (2015). Investment in agricultural research in Europe: Synthesis Report, IMPRESA Project, EC 7th Framework Programme.

EIP-AGRI EU SCAR (2012). Agricultural knowledge and innovation systems in transition - a reflection paper, Brussels.

European Commission (2018). Proposal for a Regulation of the European Parliament and of the Council establishing rules on support for strategic plans to be drawn up by Member States under the Common Agricultural Policy (CAP Strategic Plans) and financed by the European Agricultural Guarantee Fund (EAGF) and by the European Agricultural Fund for Rural Development (EAFRD) and repealing Regulation (EU) No 1305/2013 of the European Parliament and of the Council and Regulation (EU) No 1307/2013 of the European Parliament and of the Council, European Commission, Brussels, 1.6.2018

FAO (2019). Communication in research and development, FAO, http://www.fao.org/3/v9406e/v9406e02.htm

Özçatalbaş, O. (2017). Human development and research-development-extension relationships, in S. Maad (Ed.), Research and Development Evolving Trends and Practices - Towards Human, Institutional and Economic Sectors Growth. Intech Open, DOI: 10.5772/intechopen.69096

Touzard J.,Temple, L., Faure,G. and Triomphe, B. (2015). Innovation systems and knowledge communities in the agriculture and agri food sector: A literature review, Journal of Innovation Economics \& Management. 2(17), 117-142.

USDA, (2019). Agricultural research funding in the public and private sectors, USDA, https://www.ers.usda.gov/ data-products/agricultural-research-funding-in-the-public-and-private-sectors/

Weißhuhn, P., Helming,K. and Ferretti, J. (2018). Research impact assessment in agriculture-A review of approaches and impact areas.Research Evaluation. 27(1), 36-42. January, https://doi.org/10.1093/reseval/rvx034

World Bank (2006). Enhancing agricultural innovation: how to go beyond the strengthening of research systems, The International Bank for Reconstruction and Development/The World Bank, Washington DC.

Cite this article as: Hrabrin Bachev (2021). Agricultural research structure and productivity in Bulgaria. International Journal of Agricultural Sciences and Technology. 1(2), 12-26. doi: 10.51483/IJAGST.1.2.2021.12-26. 